\title{
Analysis of the Requirements for Digital Teaching Materials in Appreciation and Indonesian Literary Criticism Subject in State University of Medan
}

\author{
Fitriani Lubis ${ }^{1}$, Salmah Naelofaria ${ }^{2}$, Rumasi Simare-mare ${ }^{3}$ \\ 1,2,3Universitas Negeri Medan, Indonesia \\ Email: rianiavandi@gmail.com
}

\begin{abstract}
Entering industrial revolution 4.0 and society 5.0 era, teacher and candidate teacher preparation to be a professional should better through the increasing of competency that fit in 21st century. Indonesian Languange and Literature Education Study Program in State University of Medan as an institution that produce future candidate educator for Indonesian languange and literature has a great responsibilities to produce a teacher who have adequate 21st century's competency. The needs analysis is an initial study for research in digital teaching materials development of Appreciation and Indonesian Literary Criticism Subject in State University of Medan. The aim of this research is to look the extent of the level of need of the academic community in Indonesian Languange and Literature Education Study Program for the development of digital teaching materials. This research use descriptive method. Data are collected by observation, interview, and questionnaire. This study is a descriptive research with survey method that held between August and September 2019 in Indonesian Languange and Literature Education Study Program in State University of Medan. The population is all thirdsemester students in this study program that take Appreciation and Indonesian Literary Criticism Subject with 124 students. The sampel is selected randomly by 75 students. Futhermore, the questionnaire is also given to this study program lecturers that count 28 lecturers to know the illustration of teaching process that do based on academic community's requirements in this study program towards the high of digital teaching materials development. The findings of this study show that the academic community's requirements for the development of digital-based teaching materials in this study program is high. Students who are the sample hope that the teaching materials of that subject could be develop to be based on digital and could be access all the time by all students.
\end{abstract}

Keywords: digital teaching materials; requirements analysis

\section{Introduction}

Since the enactment of Law No. 14 Year 2005 concerning Teachers and Lecturers, the teachers position has already be approved as a profession. Thus, teacher should always actualize themselves intensively and regularly by increasing the professional competency, pedagogic, personality, and social skill. The Ministry of Education and Culture has determined that there are ten basic abilities that must be possessed by a teacher, namely: (1) Mastery of learning materials along with basic scientific concepts; (2) Ability to manage teaching and learning programs; (3) ability to manage classes; (4) ability to manage media and learning resources; (5) mastery of educational foundations; (6) ability to manage teaching and learning interactions; (7) ability to assess student achievement; (8) know the function of the guidance and counseling program; (9) knowing the administration of school administration; and (10) understanding of the principles and use of educational research results in the interest of improving the quality of teaching. (Sukmadinata, 1997: 193). 
Efforts to improve quality of education through standardization of teachers' competency be done continuously by the government. One of the efforts is to issue Permendikbud RI No. 87 Year 2013 concernings Pre-service Teacher Professional Education Program. One of the contents is the obligation for a teacher to join education program that focus on prepare bachelor of education or bachelor other degrees to have talent and ability to be a teacher in order to receive professional educator certificate. Based on the regulations outlined, it was explained that the program was organized by universities that have educational staff for educational institutions. So, indirectly the government places high hopes on the tertiary institutions that manage teacher training institutions to produce future teachers who are professional, reliable, and characterized. Hence, they can improve the quality of national education. In order to continuously develop teacher professionalism, professional teacher indicators need to be known. One indicator in pedagogical competence and professional competencies are: 1) The teacher uses teaching aids, and / or audio-visual (namely TIK) to improve studnets' motivation to achieve the purpose of teaching; 2) teachers could exploit TIK in communication and teaching process (Sustainable Professional Development) (Kemendiknas, 2010).

(Caraka \& Ika, 2016) mentions six strategies that can be carried out by the Educational Workforce Education Institution (LPTK) in producing graduates of professional teacher candidates, namely: 1) improving and developing higher education curricula based on the Indonesian National Framework Curriculum (KKNI) and National Standards for Higher Education (SNPT), 2) Strengthening effective learning systems, 3) Development of learning models based on student centered learning, 4) Strengthening of educational apprenticeship programs, 5) Strengthening of basic education courses, and 6) Developing quality of LPTK.

One of ways that be done to create alumnus that suitable with study program's vision is to be superior study program in 2023 in Indonesian language education and teaching innovation that based on the high values of north sumatera ethnic culture that have competitive power in local, national, and international level is to enhance the quality of teaching process by integrating information technology and communication. It could be done with developing learning media, and digital materials. Based on observation and researcher's experience for three years teaching this subject, there are three issues that source from three main sources namely: a) lecturers' competency, b) students' competency, c) material limitations. The ability of lecturers is closely related to the teaching competence of lecturers both concerning the competency / mastery of the substance of the field and the competence / mastery of the delivery of teaching material (learning strategies).

According to Muktar (2019) education is a conscious effort made by humans that takesplace between two people, namely educators and students whose aim is to develop and foster personalities in accordance with the values of society and culture towards a more directed and meaningful life especially parents in guide children towards physicaland spiritual development to form a good personality, intelligent and educated. Widiastusti (2019) stated that teaching material is one of the important parts in the learning process. Teaching materials should be designed and written according to the rules of learning, i.e. adapted to learning materials, arranged based on learning needs, there are evaluation materials, and the instructional materials are interesting for students to learn.

The ability of students related to the initial ability of students, students' creativity, and students' motivation, while the limitations of the equipment related to the availability of teaching materials both in terms of quality, and quantity. Lack of optimism from the three 
sources above will cause inefficient and ineffective teaching and learning process. However, from the three sources of problems and many aspects that can affect the success of the teaching and learning process, this research will only be focused or narrowed down the problem to the ability of lecturers, especially in developing learning strategies that can improve the efficiency and effectiveness of the learning program, which in turn can improve the quality students, creativity, and student independence.

One way to foster creativity in learning is to develop teaching materials in digital form (learning applications) that can be accessed anytime and anywhere through student devices. Current technological advancements are also expected to provide easier-using facilities in the world of education related to the learning process activities. The learning process is carried out by teachers and students with teaching aids in the form of teaching materials which contain various information. The information in question is in the form of a series of materials that are in accordance with the curriculum being applied.

Teaching material itself is interpreted by Majid (2011) as all forms of material used to assist teachers in carrying out teaching and learning activities in the form of both written and unwritten materials. Through this teaching material, lecturers and students are faced with learning objectives. Examples of teaching materials are books, modules, student worksheets, etc. Some of these examples illustrate that teaching materials are in the form of printed (printed). Because of the current technological developments, teaching materials are no longer printed but in digital form. This digital technology is closely related to the use of computers / laptops / notebooks / internet and supporting digital devices.

According to Weaver \& Nilson (2005), digital devices such as laptops / notebooks have various functions that are crucial for learning in the classroom. This statement makes the teacher should think openly (open minded) in today's technological developments, considering that most students are users of technology applications, especially computers. According to Anjana (2013), computer technology is no longer only used as a means of computing and data processing but also as a means of learning to design and engineer a concept and science. Computers can combine various elements of delivering information and messages and design effective teaching materials for learning with relevant material. It is the same as stated by Dinata (2013), that technological development has promised great potential in changing the way a person learns, obtains information, adjusts information, etc. On the other hand, the use of teaching materials is still in the mastery of the material.

\section{Research Methods}

This study is a descriptive research that use survey approach that implemented since August until September 2019 in Indonesian Languange and Literature Education Study Program in State University of Medan. The population is all third-semester students in that study program that take appreciation and literary criticism subject by 124 students. The number of sampel (75 students) is selected randomly. Moreover, the questionnaire is also given to study program lecturers that amount 28 lecturers to know teaching-process illustration.

Data collection techniques is by interview, observation and questionnaire. Data collection instruments utilize observation sheets and questionnaires. The observation sheet is used to obtain data about the learning activities of the subject of appreciation and Indonesian literary criticism. Open questionnaire is used to obtain data about learning resources that have been used by students, the teaching material requirements desired by students and to find out the material needed by students. Data were analyzed descriptively qualitative. 


\section{Result and Discussion}

Based on observations during the appreciation and Indonesian literary criticism, the data obtained are listed in table 1 . The results of the questionnaire distributed to students regarding the learning resources used by students are displayed in table 2 . The results of the questionnaire distributed to students related to the need for teaching materials shown in the table 3. Meanwhile, the questionnaire results related to lecturing conducted by lecturers are presented in table 4.

Table 1. Observation Results of Indonesian Literature Appreciation and Criticism Subjects

\begin{tabular}{cl} 
No & \multicolumn{1}{c}{ Observation Results } \\
1 & $\begin{array}{l}\text { Students are not focused on the learning process yet since they do not have a } \\
\text { reference book that is used in the learning process }\end{array}$ \\
\hline 2 & $\begin{array}{l}\text { Some students have not been too active in the learning process, they still } \\
\text { tend to be passive students }\end{array}$ \\
\hline 3 & There are students who talk with their friends during the learning process \\
\hline 5 & Lecturers are still the main source of learning \\
\hline
\end{tabular}

Table 2. Student Learning Resources

\begin{tabular}{clc} 
No & \multicolumn{1}{c}{ Types of Learning Resources } & Total (\%) \\
\hline 1 & Internet & $63,36 \%$ \\
\hline 2 & Reference Books & $33,76 \%$ \\
\hline 3 & Literary Works (Poetry, Short Stories, Novels) & 14,28 \\
\hline
\end{tabular}

Table 3. The Need for Student Teaching Materials

\begin{tabular}{clc}
\hline No & \multicolumn{1}{c}{ Types of Learning Resources } & Total (\%) \\
\hline 1 & Electronic Textbooks & $70,25 \%$ \\
\hline 2 & Hand Out & 10,38 \\
\hline 3 & Student Worksheet & 14,12 \\
\hline 4 & Diktat & 5,25 \\
\hline
\end{tabular}

Table 4. Description of Lecture Implementation in Study Program

\begin{tabular}{cl} 
No & \multicolumn{1}{c}{ Conclusion of Questionnaire Results } \\
\hline 1 & Most students are enthusiastic about following the lecture process with $70 \%$. \\
\hline 2 & Lecturers always motivate by giving assignments to students \\
\hline 3 & $\begin{array}{l}\text { Alternative learning media that are well used are those that are integrated } \\
\text { with internet technology }\end{array}$ \\
\hline 4 & $\begin{array}{l}\text { Learning resources that need to be developed are teaching materials that can } \\
\text { be accessed at any time by students }\end{array}$ \\
\hline 5 & $\begin{array}{l}\text { The elearningfbsunimed learning portal is good, it's just that further } \\
\text { socialization is needed to the lecturers in order to be able to use it maximally. }\end{array}$ \\
\hline
\end{tabular}

Based on observations made during lectures on appreciation and criticism of Indonesian literature, information was obtained that not all students were able to focus on learning activities. A third of students have not been able to actively participate in the learning process, this is because there are no teaching materials that can be used as a guide by students. The lack of teaching materials owned by students makes students not preparing the material to be studied yet. Since students do not yet have readiness so learning tends to go in one direction, not all students are able to participate in discussions or questions and answers. 
Learning resources used by students in lectures so far in the form of a textbook given by lecturers and several articles downloaded from the internet. As for the articles taken by students from the internet, the accuracy of the data and the source of the reference is unknown. In addition, the material obtained from textbooks mostly only discusses theories and concepts of literary appreciation in general, not yet directing students to literary appreciation activities.

Based on the questionnaire distributed to students, it was obtained that students wanted teaching materials that were developed by lecturers who used courses that were easily understood by students, were concise, and contained practice questions directing them to literary appreciation activities. In addition, they also expect teaching materials that can be connected to the device so that it is easily accessed anytime and anywhere. While in the type of teaching materials, $71.56 \%$ of students want digital based textbooks. Textbooks are one type of teaching materials that can be used as a guide for students and lecturers in carrying out lecture activities. Textbooks have a different character from reference books in general.

The creation of textbooks is adjusted to the demands of the KKNI curriculum and the mandate of Permendikti No. 44 Year 2015 concerning National Standards for Higher Education. Written and designed based on the needs of students, communicative language concepts, competencies that must be achieved, the instructional process and and feedback from students. Generally, it can be said that textbooks can develop the potential of students to become independent learners. The material expected by students in the textbooks developed is about the basic concepts of literary appreciation, appreciation of poetry and examples, appreciation of prose and examples of appreciation of several novels, and appreciation of drama performances.

Regarding learning material for literature appreciation, it is also suggested by students to enrich the concept and appreciation of gender-based literary works. Wiyatmi (2008) stated that in literature learning based on gender perspective, it is necessary to prepare learning materials that show gender equality or criticize the existence of gender injustice represented in Indonesian literary works, which are readings in literary learning. In addition, it also needs to be considered the activities and works of women writers. Through literary learning with a gender perspective, it is hoped that slowly there will be an awareness of the importance of gender equality and justice in learners.

The use of digital technology in learning is a necessity that cannot be avoided. Digital technology is described as a tool that can enhance collaboration and motivate students to reengage with education and enable them to develop their multimodal skills (Flavin, 2017; Siemens, n.d.). Utilization of digital technology is focused on local perspectives towards global as a series of responding to the higher demands and expectations. Exploration of digital technology leads to scientific methods to achieve the practical goals of an applied science. Practically, digital technology can increase the competence of students in constructing learning ways freely and developing their multimodal skills. The accelerated exploration of digital literature and hermeneutics through digital technology is a new approach and experimental effort (Steggle, 2013). This will be needed by almost all people and students in the era of globalization (Suyono, 2007). Especially the community and students based on knowledge and technology.

In addition to integrating digital technology in literary appreciation learning, appreciation also needs to be considered in the development of teaching materials. In studentoriented literary learning, the element of literary appreciation needs special attention. In this 
learning, the reader (students and lecturers must always make direct contact with literary works (Rahmanto, 2000: 5). Students must be motivated to want to read directly the literary work that will be studied or discussed together. Literary learning in schools must be able to excite students to explore the world of literature, get acquainted with literary works, and form their own opinions about it (Sujiman, 2000: 8). Thus, students feel valued their opinions and finally they will feel delighted and enjoy the literary learning they follow.

\section{Conclusion}

Based on the results of research conducted on students of the Indonesian Language and Literature Education Study Program who were sampled and several lecturers who filled out the research questionnaire, it was concluded that there was a high percentage of the needs for the development of digital-based teaching materials in Indonesian Language and Literature Education Study Program integrated with the android application system so that it can be accessed by students any time.

\section{References}

Anjana (2013). Pengembangan Media Presentasi Digital Sebagai Penunjang Mata DIklat Teknik Mikroprosesor untuk SMKN Surabaya. Jurnal Pendidikan Teknik Elektro. 02(03), 1011-1016.

Caraka, P., \& Ika, M. (2016). Strategi LPTK dalam Pengembangan Kompetensi Pedagogik Calon Guru. Jurnal Pendidikan (Teori Dan Praktik), 01(02), 96-106. http://eprints.uad.ac.id/id/eprint/6476.

Kemendiknas. 2010. Pedoman Pelaksanaan Penilaian Kinerja Guru (PK). Jakarta: Dirjen Peningkatan Mutu Pendidik dan Tenaga Kependidikan.

Majid, A. (2011). Perencanaan Pembelajaran Mengembangkan Standar Kompetensi Guru. Bandung: Remaja Rosdakarya.

Muktar, et al. (2019). Existence of Pranatal Education in Islam. BritainInternational of Linguistics, Arts and Education (BIoLAE) Journal, 1 (2): 210-223.

Rahmanto, B. 2000. "Re-Aktualisasi Pembelajaran Sastra di Sekolah dengan Fokus Siswa sebagai Pembelajar Aktif." Makalah Seminar Sehari Pengajaran Sastra di FBS Universitas Negeri Yogyakarta, 27 Oktober 2000.

Sukmadinata, N.S. 1997. Pengembangan Kurikulum, Teori dan Praktek. Bandung: Remaja Rosdakarya. Sujiman, Panuti. 2000. "Beberapa Gagasan tentang Pengajaran Sastra, Khususnya di Sekolah Lanjutan" dalam Sastra, Volume 05, September.

Weaver \& Nilson. (2005). Notebooks in Class: What are They Good for? What Can You DO with Them?”, New Directions in Teaching and Learning. Vol 101, pp 3-13.

Widiastudti, U., et al. (Development of Traditional Harmony-Based Teaching Materials Based on HOTS to Improve Student Musicality of Music Education Program at Language and Art Faculty at State University of Medan (UNIMED). Budapest International Research and Critics in Linguistics and Education (BirLE) Journal, 2 (4): 227-238.

Wiyatmi (2008). Pengantar Pengkajian Sastra. Yogyakarta: Penerbit Pustaka. 